\title{
BIOLOGICAL ACTIVITY OF METHANOL EXTRACT OF Elaeocarpus mastersii KING: ANTIOXIDANT, ANTIBACTERIAL, AND $\alpha$-GLUCOSIDASE INHIBITOR
}

\author{
Tia Okselni, Adlis Santoni, Abdi Dharma and Mai Efdi* \\ ${ }^{1}$ Department of Chemistry, Andalas University, Padang 25163, West Sumatra, Indonesia \\ *E-mail: maiefdi@sci.unand.ac.id
}

\begin{abstract}
Plants are one of the natural resources that have great biological activity and have long been used in traditional medicine. In this research, methanol extracts of root, stem bark, and leaf of Elaeocarpus mastersii King were tested to determine phenolic and flavonoid content and evaluate their biological activities as the antioxidant, antibacterial, and antidiabetic using the method of DPPH (2,2-diphenyl-1-picrylhydrazyl) assay, disc diffusion against Staphylococcus epidermidis (S. epidermidis), Staphylococcus aureus (S. aureus), Salmonella typhosa (S. typhosa), and Escherichia coli (E. coli), and inhibition of $\alpha$-glucosidase enzyme, respectively. All parts showed high phenolic content and antioxidant activity wherein the leaf extract was found to be the highest value $(340.36 \pm 2.09 \mathrm{mg}$ GAE/g $\mathrm{DW}$ and $\left.\mathrm{IC}_{50} 1.86 \pm 0.00 \mu \mathrm{g} / \mathrm{mL}\right)$ followed by the stem bark $\left(331.53 \pm 6.96 \mathrm{mg} \mathrm{GAE} / \mathrm{g} \mathrm{DW}\right.$ and $\mathrm{IC}_{50} 2.43 \pm 0.01$ $\mu \mathrm{g} / \mathrm{mL})$ and the root $\left(216.27 \pm 3.19 \mathrm{mg} \mathrm{GAE} / \mathrm{g} \mathrm{DW}\right.$ and $\left.\mathrm{IC}_{50} 3.37 \pm 0.20 \mu \mathrm{g} / \mathrm{mL}\right)$, respectively. In contrast, their flavonoid values were very low. The stem bark exhibited the highest antibacterial activity against all of the tested bacteria. The activity of $\alpha$-glucosidase inhibition revealed that the stem bark had the highest activity among all parts with the $\mathrm{IC}_{50}$ of $14.56 \pm 1.20 \mu \mathrm{g} / \mathrm{mL}$. This study demonstrates that Elaeocarpus mastersii King has a great biological activity as the antioxidant, antibacterial, and $\alpha$-glucosidase inhibitor.

Keywords: antioxidant, antibacterial, Elaeocarpus mastersii King, $\alpha$-glucosidase inhibitory activity
\end{abstract}

(C) RASĀYAN. All rights reserved

\section{INTRODUCTION}

Elaeocarpaceae is a vast plant family consisting of 12 genera which their distribution areas are tropics and subtropics. The largest genus of Elaeocarpaceae family is Elaeocarpus comprising 350 species and one of the largest distribution areas is Indonesia ${ }^{1}$. Plants of the Elaeocarpus genus have a great impact to treat various diseases such as epilepsy, hypertension, asthma, and arthritis ${ }^{2}$. Several studies showed the great biological activity of Elaeocarpus plants from crude extracts and pure compounds as the antioxidant $^{3-6}$, antimicrobial ${ }^{7-9}$, antidiabetic ${ }^{10}$, antiinflammatory ${ }^{2,11}$ cytotoxic $^{4,5,12,13}$, medicine of bronchial asthma $^{14}$, antiarthritic ${ }^{15}$, antidepressant ${ }^{16}$, and antiparkinsonian ${ }^{17}$.

Elaeocarpus mastersii King belongs to the Elaeocarpus genus used as the natural medicine of diabetic and hypertensive disease. As long as our literature study, E. mastersii King was only reported by Ito et al. ${ }^{18}$ and studied its cytotoxic activity. As the part of our ongoing program for studies about E. mastersii King plant ${ }^{19}$, we evaluated the biological activity as the antioxidant, antibacterial, and $\alpha$-glucosidase inhibitory activity from the root, stem bark, and leaf of E. mastersii King.

\section{Collection and Extraction of Plant}

\section{EXPERIMENTAL}

Plant materials (root, stem bark, and leaf) of E. mastersii King were obtained from the Riau Province, Sumatra-Indonesia. The plant materials were ground and macerated by methanol solvent. The solvent was evaporated by rotary evaporator yielding crude of methanol extracts.

Rasayan J. Chem., 12(1), 146-151(2019)

http://dx.doi.org/10.31788/RJC.2019.1215019

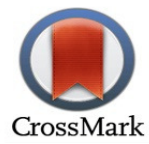




\section{Determination of Total Phenolic Content (TPC)}

Modified Folin-Ciocalteu method ${ }^{19}$ was used to determine the phenolic content of the extracts. The test tube composed of $2.5 \mathrm{ml}$ Folin-Ciocalteu reagent $(10 \%, V / V)$ and $2.0 \mathrm{~mL}$ sodium carbonate $(2 \%, W / V)$ was added with $0.5 \mathrm{~mL}$ extract of $100 \mu \mathrm{g} / \mathrm{mL}$ in methanol solution. The mixed solution was stirred and incubated for $15 \mathrm{~min}$ at $45^{\circ} \mathrm{C}$. The absorbance of the mixture was determined by spectrophotometer (PD$303 \mathrm{~S}$ Apel, Japan) at $765 \mathrm{~nm}$. The calibration curve (gallic acid, 0-80 $\mu \mathrm{g} / \mathrm{mL}$ ) was used to obtain the phenolic value and the value was presented as gallic acid equivalent (GAE) of the dry weight of the extract.

\section{Determination of Total Flavonoid Content (TFC)}

Flavonoid content of the extract was evaluated by the colorimetric method ${ }^{19}$ with slight modification. The extract of $2.0 \mathrm{~mL}(100 \mu \mathrm{g} / \mathrm{mL}$, in methanol solution) was added with aluminum chloride [0.1 mL, 10\% $(W / V)]$ and sodium acetate $(0.1 \mathrm{~mL}, 0.1 \mathrm{mM})$. The mixture was stirred and allowed to stand for $30 \mathrm{~min}$ at room temperature and its absorbance was assessed by spectrophotometer (PD-303S Apel, Japan) at 415 $\mathrm{nm}$. Rutin $(0-80 \mu \mathrm{g} / \mathrm{mL})$ was used to get the calibration curve and the flavonoid value was presented as rutin equivalent $(\mathrm{RE})$ of the dry weight of the extract.

\section{Biological Activity}

\section{Antioxidant Activity by DPPH Assay}

The DPPH method of Sen et al. ${ }^{20}$ was used to evaluate the antioxidant activity of the extract.

\section{Antibacterial Activity by Disc Diffusion Assay}

Antibacterial activity was performed by disc diffusion method ${ }^{21}$ with slight modification. $S$. epidermidis and $S$. aureus of gram-positive bacteria and $S$. typhosa and E. coli of gram-negative bacteria were used to determine the antibacterial activity of E. mastersii King extract. A Petri dish containing nutrient agar (NA) medium was added $100 \mu \mathrm{L}$ of bacterial suspension. A cotton swab was used to inoculate the tested bacteria on the surface of an agar plate. Sterilized blank paper disc of $6 \mathrm{~mm}$ diameter was filled with 10 $\mu \mathrm{L}$ extract solution $(10 \mathrm{mg} / \mathrm{mL}$ in DMSO) and placed on the top of the agar plate surface. The plate was incubated for $24 \mathrm{~h}$ at room temperature. The clear inhibition zone (including the diameter of the disc) was applied to determine the antibacterial activity. Gentamicin $(10 \mu \mathrm{g} / \mathrm{disc})$ and DMSO solution were used as the positive and negative control, respectively.

\section{a- Glucosidase Inhibitory Activity}

Antidiabetic activity was investigated by the $\alpha$-glucosidase inhibitory method described by Sancheti $e t$ $a l^{22}$

\section{Statistical Investigation}

The analysis was conducted in triplication and performed as average \pm standard deviation (SD). Statistical data were obtained by ANOVA and Duncan's multiple range test (SAS of 9.4 version) and $p$-values < 0.05 were considered as the significant difference.

\section{Total Phenolic and Flavonoid Content}

\section{RESULTS AND DISCUSSION}

Total phenolic and flavonoid value were determined by the curve of gallic acid $\left(y=0.0083 \mathrm{x}-0.0015, \mathrm{R}^{2}\right.$ $=0,9999)$ and rutin $\left(y=0.0203+0.0345, R^{2}=0.9976\right)$, respectively. All of the extracts exhibited the high phenolic and the low flavonoid value (Table-1).

Phenolic and flavonoid contents were measured by the colorimetric method based on the formation of complex compound as the reaction result of reagent and analyzed content which the blue complex is the result of reaction between Folin-Ciocalteu and phenolic compound ${ }^{23}$ and the yellow complex shows the reaction result from the aluminum (III) ion with the carbonyl and hydroxyl groups of flavonoid ${ }^{24}$.

This study showed that parts of the E. mastersii King plant had different phenolic value wherein the leaf extract was found to be the highest value $(340.36 \pm 2.09 \mathrm{mg}$ GAE/g DW) followed by the stem bark and 
root extract $(331.53 \pm 6.96$ and $216.27 \pm 3.19 \mathrm{mg} \mathrm{GAE} / \mathrm{g} \mathrm{DW}$, respectively). The same pattern was also performed by flavonoid value wherein the highest flavonoid value was found in the leaf $(21.59 \pm 1.03 \mathrm{mg}$ $\mathrm{RE} / \mathrm{g} \mathrm{DW})$ followed by the stem bark extract $(5.83 \pm 0.75 \mathrm{mg} \mathrm{RE} / \mathrm{g} \mathrm{DW})$, whereas the flavonoid value in the root was too small to be detected. These results indicated that the flavonoid was not the main phenolic compound of E. mastersii King.

Table-1: Phenolic and Flavonoid content of methanol extract from all parts of E. mastersii King

\begin{tabular}{l|c|c}
\hline Part & TPC $(\mathrm{mg} \mathrm{GAE} / \mathrm{g}$ DW $) \pm$ SD & TFC $(\mathrm{mg} \mathrm{RE} / \mathrm{g}$ DW $) \pm$ SD \\
\hline Root & $216.27 \pm 3.19^{\mathrm{c}}$ & ND \\
\hline Stem bark & $331.53 \pm 6.96^{\mathrm{b}}$ & $5.83 \pm 0.75^{\mathrm{b}}$ \\
\hline Leaf & $340.36 \pm 2.09^{\mathrm{a}}$ & $21.59 \pm 1.03^{\mathrm{a}}$ \\
\hline
\end{tabular}

ND: not detected. The values were expressed as average \pm SD $(n=3)$. The different letters indicate the significant difference between the values $(P<0.05)$

The Previous study reported the phenolic content from the fruit extract of Elaeocarpus ganitrus (232.24 $\mathrm{mg} \mathrm{GAE} / \mathrm{g} \mathrm{DW})^{25}$. This study revealed that E. mastersii King had more amount of phenolic content than the other species. Parts of plants have the different amount of phenolic due to the phenolic physiological functions associated with plant protection mechanisms against abiotic and biotic incursion ${ }^{26,27}$.

\section{Biological Activity} Antioxidant Activity

All parts of E. mastersii King revealed the strong antioxidant activity using DPPH method (Table-2).

Table-2: Antioxidant activity of methanol extract from all parts of E. mastersii King

\begin{tabular}{l|rc}
\hline Part & $\mathrm{IC}_{50}(\mu \mathrm{g} / \mathrm{mL}) \pm \mathrm{SD}$ \\
\hline Root & 3.37 & $\pm 0.02^{\mathrm{c}}$ \\
\hline Stem bark & $2.43 \quad \pm 0.01^{\mathrm{b}}$ \\
\hline Leaf & 1.86 & $\pm 0.00^{\mathrm{a}}$ \\
\hline Gallic acid & $0.48 \quad \pm 0.00$ \\
\hline
\end{tabular}

The values were expressed as average \pm SD $(n=3)$. The different letters indicate the significant difference between the values $(P<0.05)$

The DPPH method is based on the colorimetric principle in which the stabilization of free radical of 2,2diphenyl-1-picrylhydrazyl (purple color) use an electron donor of the phenolic compound to form the 2,2diphenyl-1-picrylhydrazine (yellow color) ${ }^{28}$. All parts of E. mastersii King showed the strong antioxidant activity with the similar regulation of phenolic value wherein the highest activity was obtained in the leaf $\left(\mathrm{IC}_{50} 1.86 \pm 0.00 \mu \mathrm{g} / \mathrm{mL}\right)$ followed by the stem bark and root extracts $\left(\mathrm{IC}_{50} 2.43 \pm 0.01\right.$ and $3.37 \pm 0.20$ $\mu \mathrm{g} / \mathrm{mL}$, respectively). It indicated that the phenolic compound had a significant effect on the antioxidant activity of E. mastersii King. The antioxidant activity of all parts of E. mastersii King was much better than a few species of Elaeocarpus genus, such as Elaeocarpus floribundus leaf and stem bark of methanol fractions $\left(\mathrm{IC}_{50}, 58.23 \pm 0.04 \text { and } 7.36 \pm 0.01 \mu \mathrm{g} / \mathrm{mL} \text {, respectively }\right)^{4}$ and Elaeocarpus sylvestris leaf of methanol extract $\left(\mathrm{IC}_{50}, 11.3 \pm 1.4 \mu \mathrm{g} / \mathrm{mL}\right)^{6}$.

\section{Antibacterial Activity}

The antibacterial activities from all parts of methanol extract of E. mastersii King against human pathogenic bacteria are shown in Table-3.

Disc diffusion method had been used to investigate the antibacterial activity of all parts of the E. mastersii King methanolic extract against human pathogenic bacteria, such as S. epidermidis and S. aureus of grampositive bacteria and $S$. typhosa and $E$. coli of gram-negative bacteria. The antibacterial activities were determined by the diameter of inhibition zones as the result of interaction between a disc containing an 
RASĀYAN J. Chem.

Vol. 12 | No. 1 |146 - 151| January - March | 2019

antibacterial agent and the bacteria on the surface of an agar plate. The results showed that the extract of E.mastersii King contributed the inhibition zone diameters ranging from 6.90 to $8.90 \mathrm{~mm}$ for grampositive bacteria and from 6.93 to $10.37 \mathrm{~mm}$ for gram-negative bacteria. These results exhibited that the extract of this plant was more sensitive to gram-negative bacteria. This result was supported by the previous study on the other species of Elaeocarpus genus which leaf extract of Elaeocarpus ganitrus also performed a good activity against gram-negative bacteria (eg. Pseudomonas aeruginosa and Klebsiella pneumoniae $)^{9}$. Gram-negative bacteria consist of a thinner layer of peptidoglycan than gram-positive bacteria. Peptidoglycan has an important role in the survival of bacteria in the hypotonic environment. This layer is the attack center of antibacterial agents that can cause cell wall damage resulting in cell death $^{29}$. Thereby, the cell wall of gram-negative bacteria can be damaged easily.

Table-3: Antibacterial activity of methanol extract from all parts of E. mastersii King

\begin{tabular}{l|c|c|c|c}
\hline \multirow{2}{*}{ Part } & \multicolumn{3}{|c}{ Zone of Inhibition (mm) } \\
\cline { 2 - 5 } & \multicolumn{2}{|c}{ Gram-positive } & \multicolumn{2}{c}{ Gram-negative } \\
\cline { 2 - 5 } & S. epidermidis & S. aureus & S. typhosa & E. coli \\
\hline Root $^{*}$ & $7.00 \pm 0.26^{\mathrm{b}}$ & $6.90 \pm 0.10^{\mathrm{b}}$ & $7.27 \pm 0.21^{\mathrm{b}}$ & $8.30 \pm 0.30^{\mathrm{b}}$ \\
\hline Stem bark $^{*}$ & $8.60 \pm 0.62^{\mathrm{a}}$ & $8.90 \pm 0.50^{\mathrm{a}}$ & $9.10 \pm 0.46^{\mathrm{a}}$ & $10.37 \pm 0.51^{\mathrm{a}}$ \\
\hline Leaf $^{*}$ & $7.63 \pm 0.47^{\mathrm{b}}$ & $7.40 \pm 0.53^{\mathrm{b}}$ & $6.93 \pm 0.12^{\mathrm{b}}$ & $7.13 \pm 0.40^{\mathrm{c}}$ \\
\hline Gentamicin $^{* * *}$ & $17.83 \pm 0.35$ & $16.50 \pm 0.17$ & $16.90 \pm 0.10$ & $12.47 \pm 0.55$ \\
\hline
\end{tabular}

*Concentration of the extract $(100 \mu \mathrm{g} / \mathrm{disc})$, **concentration of gentamicin $(10 \mu \mathrm{g} / \mathrm{disc})$

The values were expressed as average $\pm \mathrm{SD}(\mathrm{n}=3)$. The different letters indicate the significant difference between the values $(P<0.05)$

Antibacterial activities of parts of E. mastersii King were in the following order stem bark $>$ leaf $>$ root for gram-positive bacteria, whereas the gram-negative bacteria were stem bark $>$ root $>$ leaf. The stem bark had the highest antibacterial activity against all bacteria. It could be due to the presence of ellagic acid, steroid, alkaloid and phenolic compounds which were found in the stem bark of E. mastersii King $^{18,19}$ and were known to provide the antibacterial activity ${ }^{30-32}$.

\section{a-Glucosidase Inhibitory Activity}

The antidiabetic activity of all parts of E. mastersii King (Table-4) had been determined by the inhibition of the $\alpha$-glucosidase enzyme.

Table-4: The $\alpha$-glucosidase inhibitory activity of methanol extract from all parts of $E$. mastersii King

\begin{tabular}{l|rc}
\hline Part & $\mathrm{IC}_{50}(\mu \mathrm{g} / \mathrm{mL}) \pm \mathrm{SD}$ \\
\hline Root & $60.57 \quad \pm 2.84^{\mathrm{b}}$ \\
\hline Stem bark & $14.56 \quad \pm 1.20^{\mathrm{a}}$ \\
\hline Leaf & 96.36 & $\pm 4.67^{\mathrm{c}}$ \\
\hline Acarbose & $0.13 \quad \pm 0.00$ \\
\hline
\end{tabular}

The values were expressed as average \pm SD (n=3). The different letters indicate the significant difference between the values $(P<0.05)$

Antidiabetic properties of parts of E. mastersii King were obtained from the $\alpha$-glucosidase inhibitory activity. Inhibition of $\alpha$-glucosidase enzyme can prevent the carbohydrate digestion and delay the glucose absorption resulting in decreasing of blood glucose levels ${ }^{33}$. This study was investigated by the amount of p-nitrophenol released in the reaction results between 4-nitrophenyl $\alpha$-D-glucopyranoside and $\alpha$ glucosidase enzyme ${ }^{22}$.

The results showed the good $\alpha$-glucosidase inhibitory activity of E. mastersii King and as shown in Table 4, the highest $\mathrm{IC}_{50}$ value was found in the stem bark $\left(\mathrm{IC}_{50} 14.56 \pm 1.20 \mu \mathrm{g} / \mathrm{mL}\right.$ ). This ability could be due to the presence of ellagic acid, steroid, alkaloid, and phenolic compounds in the stem bark ${ }^{18,19}$ which were known to provide a significant antidiabetic activity ${ }^{34,35}$. The $\alpha$-glucosidase inhibitory activity of $E$. 
RASĀYAN J. Chem.

Vol. 12 | No. 1 |146 - 151| January - March | 2019

mastersii King was known to be better than the other species, as Elaeocarpus sylvestris with the $\mathrm{IC}_{50}$ value of $74.4 \pm 0.9 \mu \mathrm{g} / \mathrm{mL}^{10}$.

\section{CONCLUSION}

This study exhibited that all parts of E. mastersii King have high phenolic content and antioxidant activity. The stem bark had the highest antibacterial and $\alpha$-glucosidase inhibitory activity among all parts. Therefore, E. mastersii King has a great biological activity as the antioxidant, antibacterial, and $\alpha$ glucosidase inhibitor. This ability could be due to the presence of secondary metabolites such as phenolic, alkaloid, steroid, and ellagic acid compounds.

\section{ACKNOWLEDGMENT}

The authors would like to thank the Ministry of Research and Technology of Indonesia for financial support (Grant number: 050/SP2H/LT/DRPM/2018).

\section{REFERENCES}

1. M.J.E. Coode, 2004, Elaeocarpaceae, in: K. Kubitzki (Ed.), Flowering Plants-Dicotyledons, The Families and Genera of Vascular Plants, vol 6, Springer-Verlag Berlin Heidelberg, New York, pp. 135-144, DOI: $10.1007 / 978-3-662-07257-8$

2. R.K. Singh, S.B. Acharya, and S.K. Bhattacharya, Phyther. Res., 14(1), 36(2000), DOI: 10.1002/(SICI)1099-1573(200002)14:1<36::AID-PTR541>3.0.CO;2-J

3. L. Jayasinghe, N.R. Amarasinghe, B.G.S. Arundathie, G.K. Rupasinghe, N.H.A.N. Jayatilake, and Y. Fujimoto, Nat. Prod. Res., 26, 717(2012), DOI: 10.1080/14786419.2010.551514

4. R. Utami, N. Khalid, M.A. Sukari, M. Rahmani, A.B. Abdul, and Dachriyanus, Pak. J. Pharm. Sci., 26, 245(2013).

5. M.N. Parvin, S. Sarwar, S.A. Chowdhury, H.M. Zakaria, and N.H. Huda, Stamford J. Pharm. Sci., 2(2), 86(2009), DOI: 10.3329/sjps.v2i2.5829

6. A.I. Prihantini, S. Tachibana, and K. Itoh, Procedia Environ. Sci., 28, 758(2015), DOI: 10.1016/j.proenv.2015.07.089

7. R.K. Singh and G. Nath, Phyther. Res., 13, 448(1999), DOI: 10.1002/(SICI)10991573(199908/09)13:5<448::AID-PTR480>3.0.CO;2-6

8. I. Jayashree, D.H. Geetha, and M. Rajeswari, Int. J. Pharm. Sci. Res., 5(8), 3467(2014), DOI: 10.13040/IJPSR.0975-8232.5(8).3467-72

9. G. Kumar, L. Karthik, and K.V.B. Rao, Elixir. Bio Tech., 40, 5384(2011).

10. A.I. Prihantini, S. Tachibana, and K. Itoh, Pakistan J. Biol. Sci., 17(10), 1106(2014), DOI: 10.3923/pjbs.2014.1106.1114

11. O. Kwon, K. Ahn, J. Park, H. Jang, H. Joung, H. Lee, and S. Oh, Inflammation, 35 (2), 535(2012), DOI: $10.1007 / \mathrm{s} 10753-011-9343-3$

12. X. Fang, C.H. Phoebe, J.M. Pezzuto, H.H.S. Fong, and N.R. Farnsworth, J. Nat. Prod., 47(6), 988(1984), DOI: $10.1021 / \mathrm{np50036a013}$

13. D. Meng, S. Qiang, L. Lou, and W. Zhao, Planta. Med., 74, 1741(2008), DOI: 10.1055/s-20081081356

14. R.K. Singh, S.K. Bhattacharya, and S.B. Acharya, Phytomedicine, 7(3), 205(2000), DOI: 10.1016/S0944-7113(00)80005-7

15. D.H. Geetha, I. Jayashree, and M. Rajeswari, Int. J. Pharm. Sci. Res., 6(6), 2649(2015), DOI: 10.13040/IJPSR.0975-8232.6(6).2649-51

16. A. Dadhich, N.D. Jasuja, S. Chandra, and G. Sharma, Int. J. Pharm. Sci. Res., 5(7), 2807(2014), DOI: $10.13040 /$ IJPSR.0975-8232.5(7).2807-12

17. H.G. Bagewadi and A.K.A. Khan, Int. J. Basic Clin. Pharmacol., 4(1), 102(2015), DOI: 10.5455/2319-2003.ijbcp20150218

18. A. Ito, H. Chai, D. Lee, L.B.S. Kardono, S. Riswan, N.R. Farnsworth, G.A. Cordell, J.M. Pezzuto, and A.D. Kinghorn, Phytochemistry, 61, 171(2002), DOI: 10.1016/S0031-9422(02)00232-7

19. T. Okselni, A. Santoni, A. Dharma, and M. Efdi, Rasayan Journal of Chemistry,11(3), 1211(2018), DOI:10.31788/RJC.2018.1133058 
RASĀYAN J. Chem.

Vol. 12 | No. 1 |146 - 151| January - March | 2019

20. S. Sen, B. De, N. Devanna, and R. Chakraborty, Chin. J. Nat. Med., 11(2), 149(2013), DOI: 10.1016/S1875-5364(13)60042-4

21. D. Handayani and M.A Artasasta, J. Appl. Pharm. Sci., 7(5), 66(2017), DOI: 10.7324/JAPS.2017.70512

22. S. Sancheti, S. Sancheti, and S. Seo, Am. J. Pharmacol. Toxicol., 4(1), 8(2009), DOI: 10.3844/ajptsp.2009.8.11

23. P. Schofield, D.M. Mbugua, and A.N. Pell, Animal Feed Science and Technology, 91, 21(2001), DOI: $10.1016 / \mathrm{S} 0377-8401(01) 00228-0$

24. M. Popova, V. Bankova, D. Butovska, V. Petkov, B.N. Damyanova, A.G. Sabatini, G.L. Marcazzan, and S. Bogdanov, Phytochemical Analysis, 15, 235(2004), DOI: 10.1002.pca.777

25. S. Hardainiyan, B.C. Nandy, and R. Saxena, Int. J. Pharm. Pharm .Sci., 7(6), 415 (2015).

26. L.J. Jing, M. Mohamed, A. Rahmat, and M.F.A. Bakar, J. Med. Plants. Res., 4(1), 27(2010), DOI: 10.5897/JMPR09.308

27. A. Bhattacharya, P. Sood, and V. Citovsky, Mol. Plant. Pathol., 11(5), 705(2010), DOI: 10.1111/J.1364-3703.2010.00625.X

28. M.G. Miguel, Flavour. Fragr. J., 25, 291(2010), DOI: 10.1002/ffj.1961

29. H.C. Neu and T.D. Gootz, 1996, Antimicrobial Chemotherapy, in: S. Baron (Ed.), Medical Microbiology $4^{\text {th }}$ ed, University of Texas Medical Branch at Galveston, Galveston (TX), Chapter 11. [ONLINE, Cited 2017 October 21]. Available from: https://www.ncbi.nlm.nih.gov/books/NBK7986/

30. Y. Miyasaki, J.D. Rabenstein, J. Rhea, M. Crouch, U.M. Mocek, P.E. Kittell, M.A. Morgan, W.S. Nichols, M.M.V. Benschoten, W.D. Hardy, and G.Y. Liu, Plos. One., 8(4), 1(2013), DOI: 10.1371/journal.pone.0061594

31. A.C. Keller, M.P. Maillard, and K. Hostettmann, Phytochemistry, 41(4), 1041(1996), DOI: 10.1016/0031-9422(95)00762-8

32. T.P.T Cushnie, B. Cushnie, and A.J. Lamb, International Journal of Antimicrobial Agents, 44(5), 377(2014), DOI: 10.1016/j.ijantimicag.2014.06.001

33. C. Sumrall and M.J. Bouldin, 2009, Diabetes Mellitus Management, in: W.D. Linn, M.R. Wofford, M.E. O'Keefe, and L.M. Posey (Eds.), Pharmacotherapy in Primary Care, McGraw-Hill, New York, pp. 279-292, DOI: $10.1036 / 0071456120$

34. M. Jung, M. Park, H.C. Lee, Y. Kang, E.S. Kang, and S.K. Kim, Curr. Med. Chem., 13, 1203(2006), DOI: $10.2174 / 092986706776360860$

35. S.H. Tiong, C.Y. Looi, H. Hazni, A. Arya, M. Paydar, W.F. Wong, S. Cheah, M.R. Mustafa, and K. Awang, Molecules, 18, 9770(2013), DOI: 10.3390/molecules 18089770

[RJC-5019/2018] 